\title{
Relationships between Soil Depth and Terrain Attributes in a Semi Arid Hilly Region in Western Iran
}

\author{
Abdolmohammad MEHNATKESH ${ }^{1}$, Shamsollah AYOUBI ${ }^{*}$, Ahmad JALALIAN ${ }^{1}$, Kanwar L. \\ SAHRAWAT ${ }^{2}$ \\ 1 Department of Soil Science, College of Agriculture, IsfahanUniversity of Technology, Isfahan 84156-83111, Iran \\ 2 International Crop Research Institute for the Semi Arid Tropic (ICRISAT), Patancheru 502 324, Andhra Pradesh, India \\ *Corresponding Author, e-mail: ayoubi@cc.iut.ac.ir; Tel: +98-311-3913475; Fax: +98-311-3913471
}

(C) Science Press and Institute of Mountain Hazards and Environment, CAS and Springer-Verlag Berlin Heidelberg 2013

\begin{abstract}
Soil depth generally varies in mountainous regions in rather complex ways. Conventional soil survey methods for evaluating the soil depth in mountainous and hilly regions require a lot of time, effort and consequently relatively large budget to perform. This study was conducted to explore the relationships between soil depth and topographic attributes in a hilly region in western Iran. For this, one hundred sampling points were selected using randomly stratified methodology, and considering all geomorphic surfaces including summit, shoulder, backslope, footslope and toeslope; and soil depth was actually measured. Eleven primary and secondary topographic attributes were derived from the digital elevation model (DEM) at the study area. The result of multiple linear regression indicated that slope, wetness index, catchment area and sediment transport index, which were included in the model, could explain about $76 \%$ of total variability in soil depth at the selected site. This proposed approach may be applicable to other hilly regions in the semi-arid areas at a larger scale.
\end{abstract}

Keywords: Soil depth prediction; Topographic attributes; Digital elevation model; Soil-landscape model

\section{Introduction}

Soil depth is defined as the depth from the surface to more-or-less consolidated material and

Received: 23 May 2012

Accepted: 22 September 2012 can be considered as the most crucial soil indicator, affecting desertification and degradation in disturbed ecosystems. Vegetation under semi-arid climatic conditions is principally controlled by soil water storage capacity and therefore, soil depth (Kuriakose et al. 2009). Soil depth decreases as a result of soil erosion; and soil erosion is a serious threat to soil quality and productivity in the hilly areas of western Iran (Afshar et al. 2010). Solum depth is controlled by overland and intra-soil water dynamics, depending on the relief. This results from the dependence of soil depth on the spatial differentiation of moisture according to land surface morphology (Moore et al. 1991).

The effects of soil erosion on agricultural productivity depend largely on the thickness and quality of the topsoil, and on the nature of the subsoil. Most hilly soils in steep slopes (shoulder position) are shallow or have some undesirable properties in the subsoil such as petrocalcic horizon, or bedrock that adversely affect growth and yield of crops (Norouzi et al. 2009; Meyer et al. 2007).

Soil depth varies as a function of many different factors, including slope, land use, curvature, parent material, weathering rate, climate, vegetation cover, upslope contributing area, and lithology (Minasny and McBratney 1999; Kuriakose et al. 2009). Topography, one of the major soil forming factors, controls various soil properties. Soil scientists have identified topography as one of the pedogenic factors (Florinsky et al. 2002), which significantly 
influences the spatial distribution of soil properties and soil depth. Thus, quantitative information on the topographic attributes has been applied in the form of digital terrain models (DTMs). The prediction of soil depth by topographic attributes depends mainly on: i) the spatial scale of topographic variation in the area, ii) the nature of the processes that are responsible for spatial variation in soil depth, and iii) the degree to which terrain-soil relationships have been disturbed by human activities (Boer et al. 1996; Kuriakose et al. 2009; Vanwalleghem et al. 2010; Ziadat 2010)

Since, the soil properties prediction based on DTM could describe the relationships between soil and topographic attributes at a point in the landscape (Thompson et al. 1997), quantitative topographic data are often used in soil studies including modeling and prediction of soil properties. Field data acquisition techniques such as drilling or trench excavation are labor-intensive, costly and involve extensive fieldwork including sampling and laboratory analysis. They can be effectively complemented by soil-landscape models by using auxiliary variables, which are time, labor and cost effective. Various terrain attributes for improved prediction of soil depth have been employed including slope and curvature (Tsai et al. 2001) as compound terrain index (Saulnier et al. 1997).

The integration of the auxiliary terrain attributes can be made by different techniques. Many studies have been applied including geostatistical approaches to use terrain attributes as auxiliary variables for the estimation of soil properties (e.g. Kalivas et al. 2002; McBratney et al. 2003; Mueller and Pierce 2003; Penížek and Borůvka 2006). Also, multiple linear regressions have been widely used for predicting soil properties and soil depth at the watershed scale (Florinsky et al. 2002). Canonical correspondence analyses (Odeh et al. 1991), expert knowledge and fuzzy logic (Zhu et al. 2001), principal component analysis and maximum likelihood classification (Boer et al. 1996), and multiple linear regression and maximum likelihood classification (Ziadat 2005) have also been used to predict soil depth. Logistic regression methods also have been successfully used in predicting soil classes (Campling et al. 2002; Debella-Gilo et al. 2009; Hengl et al. 2007).
Calcareous hilly regions cover much of mountainous region in western Iran. The knowledge about the quantitative information for soil depth variability plays a vital role in the precise management of landscapes in these hillslopes. Traditional soil surveys for this purpose are much time, labor and cost consuming. Therefore, developing regional soil landscape models using the easily available data such as DEM and its derivations as an alternative way was the key objective of this study. Little attention has been paid to predict soil depth using topographic attributes in the arid and semiarid hilly regions therefore, this study was conducted to explore the relationships of soil depth with topographic attributes in a hilly region of western Iran.

\section{Materials and Methods}

\subsection{Description of the study area}

The study area is located at Koohrang district between $32^{\circ} 20^{\prime}$ to $32^{\circ} 30^{\prime} \mathrm{N}$ latitudes and $50^{\circ} 14^{\prime}$ to $50^{\circ} 24^{\prime}$ E longitudes, in Charmahal and Bakhtiari province, western Iran (Figure 1). The mean elevation of this area is approximately $2,510 \mathrm{~m}$ a.s.l. Mean annual temperature is $9.4{ }^{\circ} \mathrm{C}$ and the average annual precipitation is $1,400 \mathrm{~mm}$, which falls mainly from November to May (Iran Metrological Organization 2012). Soil moisture and temperature regimes in this area are Xeric and Mesic, respectively (Soil Survey Staff 2006). The field sites with an area of 30,000 ha are located on the hillslopes at about 20\% transversal slope.

The parent material and bedrocks mainly included marly limestone with interlayer of limestone which is ascribed to Oligomiocene period. Table 1 presents selected morphological, physical and chemical properties of representative soil profiles in various land form positions in the area studied. Our results showed that the soils are predominantly calcareous (high calcium carbonate equivalent) because they have developed on calcareous parent material. The soils mainly had soil texture of silty clay and clay. The soils studied are poor in soil organic matter induced by extensive cultivation and show alkaline acidity controlled by $\mathrm{CaCO}_{3}$.

The soils at the site are classified as Typic 


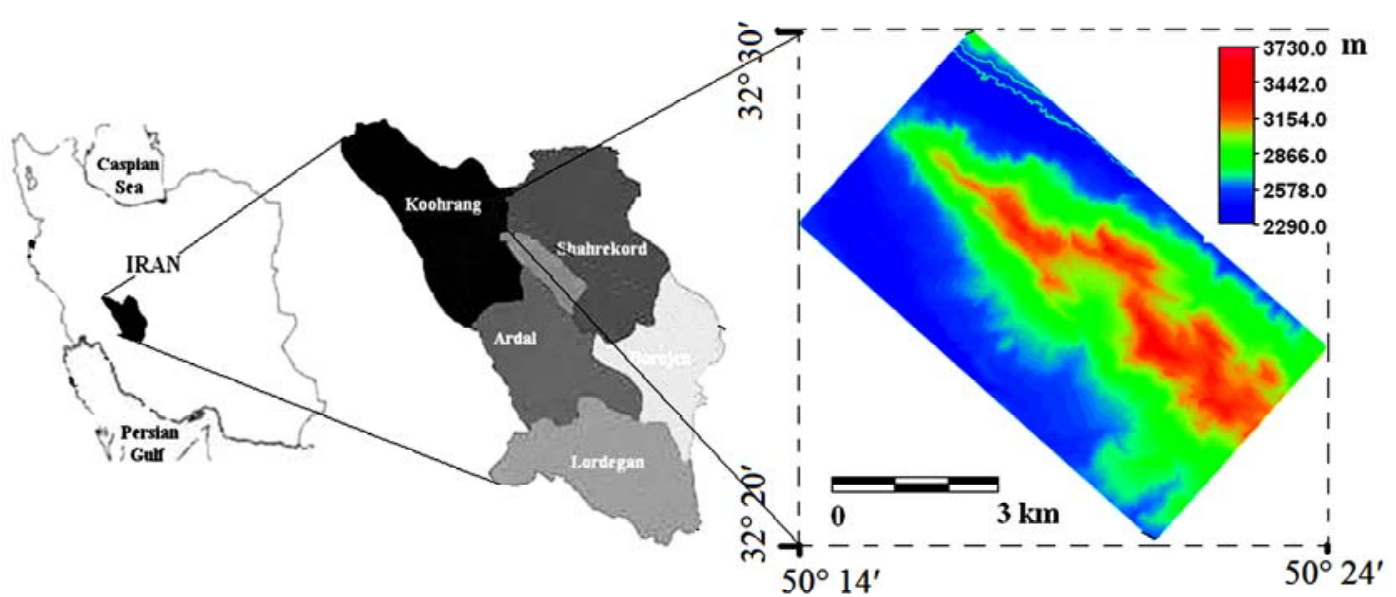

Figure 1 Location of the studied area in Chelgerd district, Charmahal and Bakhtiari province, Iran

Table 1 Selected soil morphological, physical, and chemical properties, and soil classification (Soil Survey Staff, 2006) for the representative soil profiles in different land form positions in the area studied. CCE: calcium carbonate equivalent; SOM: soil organic matter

\begin{tabular}{|c|c|c|c|c|c|c|c|c|c|c|}
\hline Depth(cm) & Horizon & $\begin{array}{l}\text { Color } \\
\text { (moist) }\end{array}$ & Texture & $\begin{array}{c}\text { Gravel } \\
\%\end{array}$ & $\begin{array}{c}\text { Sand } \\
\%\end{array}$ & $\begin{array}{l}\text { Silt } \\
\%\end{array}$ & $\begin{array}{c}\text { Clay } \\
\%\end{array}$ & $\begin{array}{c}\mathrm{SOM} \\
\%\end{array}$ & $\begin{array}{c}\mathrm{CCE} \\
\%\end{array}$ & $\mathrm{pH}$ \\
\hline \multicolumn{11}{|c|}{ Summit position (Typic Calcixerepts) } \\
\hline $0-15$ & Ap & $7.5 \mathrm{YR} 4 / 4$ & Silty clay & 9 & 10.5 & 40.5 & 49.0 & 1.018 & 16.67 & 7.66 \\
\hline $15-40$ & Bw & $10 Y R$ 5/6 & Clay & 39 & 11.0 & 34.5 & 54.5 & 1.035 & 26.00 & $7 \cdot 58$ \\
\hline $40-70$ & $\mathrm{Bk}_{1}$ & $10 Y R 5 / 4$ & Silty clay & 15 & 2.0 & 42.0 & 56.0 & 1.560 & 19.75 & $7 \cdot 47$ \\
\hline $70-120$ & $\mathrm{Bk}_{2}$ & $7.5 \mathrm{YR} 5 / 4$ & Silty clay & 23 & 12.0 & 40.0 & 48.0 & 0.449 & 42.50 & 7.66 \\
\hline \multicolumn{11}{|c|}{ Shoulder position( Typic Xerorthents) } \\
\hline $0-10$ & Ap & $7.5 \mathrm{YR} 5 / 4$ & Clay & 13 & 20.5 & 37.0 & 42.5 & 0.965 & 37.88 & $7 \cdot 54$ \\
\hline $10-27$ & $\mathrm{Bw}_{1}$ & $7 \cdot 5 \mathrm{YR} 5 / 4$ & Silty clay loam & 15 & 16.0 & 45.0 & 39.0 & 0.896 & 19.06 & 7.77 \\
\hline $27-58$ & $\mathrm{Bw}_{2}$ & $7.5 \mathrm{YR} / 4$ & Clay & 19 & 27.0 & 32.5 & 40.5 & 0.702 & $45 \cdot 50$ & 7.72 \\
\hline $58-90$ & $\mathrm{BC}$ & $7.5 \mathrm{YR} 6 / 6$ & Loam & 10 & 29.0 & 49.0 & 22.0 & 0.254 & $47 \cdot 50$ & 7.79 \\
\hline $90^{+}$ & $\mathrm{C}$ & - & - & - & - & - & - & - & - & - \\
\hline \multicolumn{11}{|c|}{ Back slope position (Calcic Haploxerepts) } \\
\hline $0-10$ & Ap & $5 \mathrm{YR} 4 / 4$ & Clay loam & 9 & 21.00 & 44.50 & 34.50 & 1.109 & 19.19 & 7.63 \\
\hline $10-28$ & $\mathrm{Bd}$ & $2.5 \mathrm{Y} 4 / 4$ & Silty clay & 26 & 10.00 & 42.00 & 48.00 & 1.300 & 1.50 & $7 \cdot 58$ \\
\hline $28-54$ & $\mathrm{Bk}_{1}$ & $5 \mathrm{YR} 4 / 4$ & Clay & 32 & 13.00 & $35 \cdot 50$ & 51.50 & 0.701 & 4.90 & 7.62 \\
\hline $54-100$ & $\mathrm{Bk}_{2}$ & $5 \mathrm{YR} 4 / 6$ & Clay & 20 & 20.00 & 38.00 & 42.00 & 0.191 & 14.75 & 7.63 \\
\hline $100-130$ & $\mathrm{BC}$ & 10YR 6/6 & $\begin{array}{l}\text { Sandy clay } \\
\text { loam }\end{array}$ & 22 & 53.00 & 20.50 & 26.50 & 0.431 & 48.04 & 7.85 \\
\hline \multicolumn{11}{|c|}{ Footslope position (Chromic Calcixererts) } \\
\hline $0-18$ & Ap & $7 \cdot 5 \mathrm{YR} 4 / 4$ & Clay & 10 & 15.00 & 38.50 & 46.50 & 0.907 & 23.74 & $7 \cdot 54$ \\
\hline $18-39$ & Btkss $_{1}$ & $10 Y R 5 / 3$ & Clay & 11 & 15.00 & 33.00 & 52.00 & 1.473 & 11.50 & 7.72 \\
\hline $39-130$ & Btkss $_{2}$ & $10 Y R 5 / 4$ & Clay & 25 & 7.00 & $35 \cdot 50$ & $57 \cdot 50$ & 0.341 & 26.96 & 7.83 \\
\hline $130-150^{+}$ & $\mathrm{Bk}$ & $5 \mathrm{YR} 5 / 4$ & Clay & 30 & 16.00 & 28.00 & 56.00 & 0.431 & 48.04 & 7.85 \\
\hline \multicolumn{11}{|c|}{ Toeslope position (Chromic Calcixererts) } \\
\hline $0-30$ & $\mathrm{Ap}_{1}$ & $10 Y R 5 / 4$ & Clay & 5 & 9.00 & 41.00 & 50.00 & 0.904 & 22.73 & $7 \cdot 55$ \\
\hline $30-65$ & $\mathrm{Bw}$ & $10 Y R 5 / 4$ & Silty clay & 15 & 8.00 & 43.00 & 49.00 & 0.799 & 20.00 & $7 \cdot 54$ \\
\hline $65-122$ & Btkss $_{1}$ & $7 \cdot 5 \mathrm{YR} / 4$ & Clay & 34 & 10.00 & 34.50 & $55 \cdot 50$ & 0.593 & 26.96 & 7.66 \\
\hline $122-150^{+}$ & Btkss $_{2}$ & $5 \mathrm{YR} 5 / 4$ & Silty clay & 24 & 12.00 & 43.00 & 45.00 & 0.644 & 38.50 & 7.67 \\
\hline
\end{tabular}

Calcixerepts, Typic Xerorthents and Calcic Haploxerepts for the representative excavated profiles in summit, shoulder and backslope, respectively (Table 1). The soils located at footslope and toeslope were classified as Chromic Calcixererts (Soil Survey Staff 2006). 


\subsection{Field work and soil depth measurements}

Field work was conducted in 2009 summer. Because of the variable terrain, purposive sampling of representative sites was used. Measurements were made in twenty representative hillslopes of the studied area. At the selected site, one hundred points were selected using randomly stratified methodology, considering all geomorphic surfaces including summit, shoulder, backslope, footslope and toeslope during sampling. The positions of the sampling points were recorded by a GPS (model: 76CSx). Overall, 100 profiles were dug and described according to the Soil Survey Manual (2006); and the solum thickness was measured for each profile (Figure 2).

\subsection{Digital terrain modeling (DTM)}

DEM data were created by using a 1:2,5000 topography map with $10 \mathrm{~m}$ elevation resolution. The raster format of DEM was produced by using interpolation algorithm in ILWIS software (ITC 1997). Then topographical indices were generated from the DEM using ILWIS software and DIGEM software (http//:www.geogr.uni-goettingen.de/ pg/saga/digem, Accessed: 22 February 2011). Moor et al. (1991) divided the terrain attributes in two categories--primary and secondary (compound) attributes; primary attributes are calculated directly from DEMs and included elevation (Elev), slope (Slop), aspect (ASP), catchment area (CA), dispersal area (DispA), plan curvature (PLanC), profile curvature (ProfC), tangential curvature (TangC), shaded relief (Shaded). The definitions of the selected topographic attributes are provided in Table 2. Secondary or compound attributes involve combinations of the primary attributes, and are indices that describe the spatial variability of specific processes occurring in the landscape such as soil water content or the potential for sheet erosion, stream power index (SPI), wetness index (WI), and sediment transport index (STI).Wetness index is calculated by Equation 1 (Wilson and Gallant 2000).

$$
W I=\ln \left(\frac{A_{s}}{\tan \beta}\right)
$$

where, " $A_{s}$ " is the specific catchment area and " $\beta$ " is the slope degree.

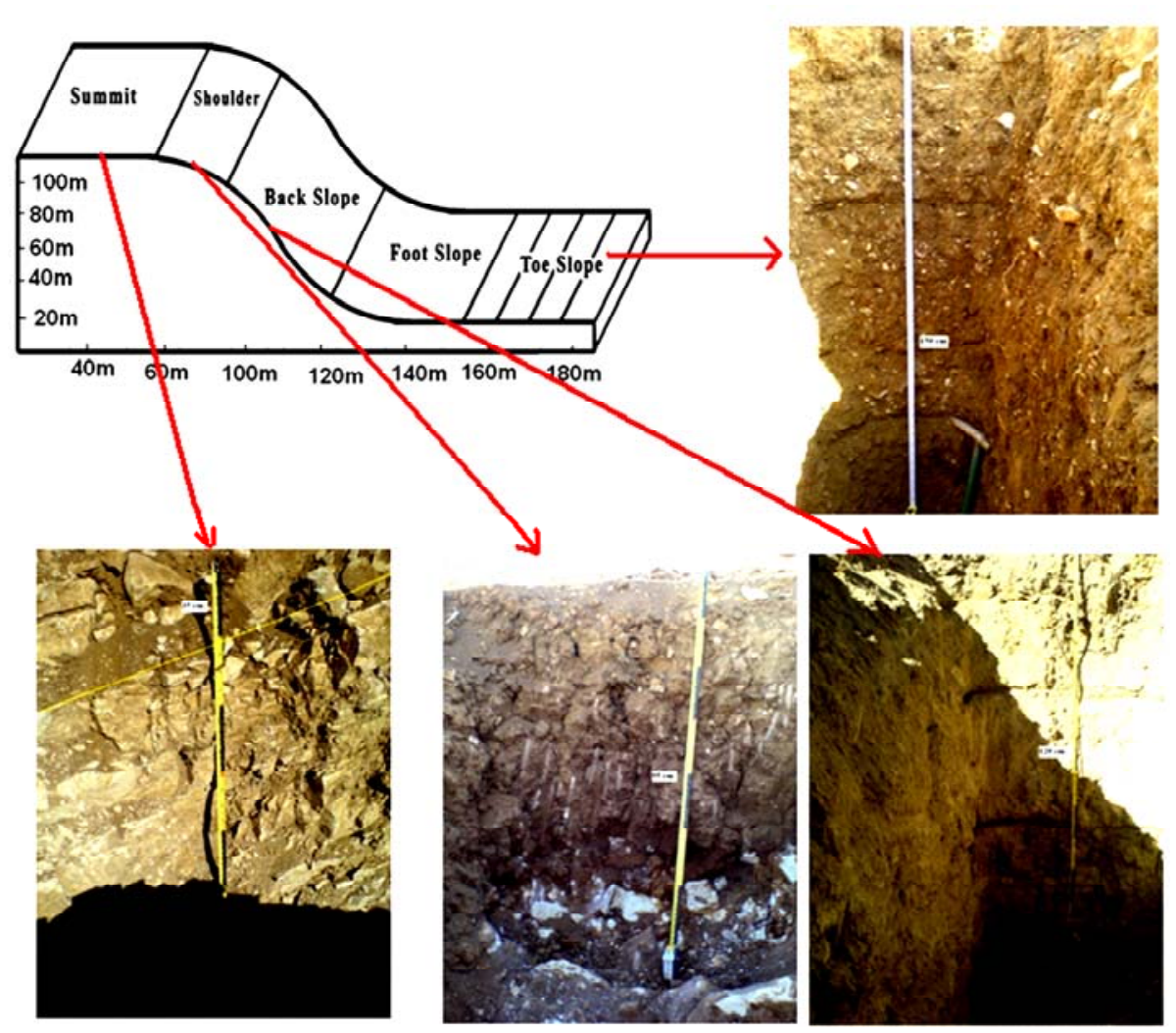

Figure 2 Soil depth measured at different slope positions in the selected hillslopes 
Table 2 Definitions of topographic attributes (Moore et al. 1991; Florinsky et al. 2002; Basso 2005)

\begin{tabular}{|c|c|}
\hline Variable & Definition \\
\hline Wetness index (WI) & $\begin{array}{l}\text { Sets catchment area in relation to the slope gradient. It has been used to } \\
\text { characterize the spatial distribution of zones of surface saturation and soil water } \\
\text { content in landscapes. It shows the extent of flow accumulation. } \\
W I=\ln \left(\frac{A_{s}}{\tan \beta}\right)\end{array}$ \\
\hline $\begin{array}{l}\text { Profile curvature (PROFC) } \\
1 / \mathrm{m}\end{array}$ & $\begin{array}{l}\text { Curvature of a surface in the direction of steepest slope. It is a measure of the rate } \\
\text { of change of the potential gradient, and is important for water flow and sediment } \\
\text { transport processes. It decelerates substance flow }\end{array}$ \\
\hline Slope (S) & $\begin{array}{l}\text { Maximum rate of change in elevation from each DEM cell. It is the gradient at a } \\
\text { specified point, and is used to identify the steepest of the gradients between a } \\
\text { point and its neighbors. It shows the velocity of substance flows. } \\
S=\arctan \sqrt{p^{2}+q^{2} a}\end{array}$ \\
\hline $\begin{array}{l}\text { Plan curvature (PLANC) } \\
1 / \mathrm{m}\end{array}$ & $\begin{array}{l}\text { Curvature of a surface perpendicular to the direction of steepest slope. It is a } \\
\text { measure of the convergence or divergence and thus indicates water content. }\end{array}$ \\
\hline $\begin{array}{l}\text { Sediment transport index } \\
\text { (STI) }\end{array}$ & $\begin{array}{l}\text { This term accounts for the effects of topography on erosion and soil loss. } \\
S T I=(S C A / \mathbf{2 2 . 1 3})^{m}\left(\frac{\sin S}{\mathbf{0 . 0 8 9 6}}\right)^{n}\end{array}$ \\
\hline $\begin{array}{l}\text { Mean curvature (MEANC) } \\
1 / \mathrm{m}\end{array}$ & $\begin{array}{l}\text { Average of plan and profile curvature. It shows the degree of flow accumulation. } \\
H=\frac{k h+k v}{2}\end{array}$ \\
\hline $\begin{array}{l}\text { Specific catchment area } \\
\text { (SCA) } \mathrm{m}^{2} / \mathrm{m}\end{array}$ & $\begin{array}{l}\text { Upslope area per unit width of contour, and it is ratio of an area of an exclusive } \\
\text { figure formed on the one hand by a contour intercept with a given point on the } \\
\text { land surface and is a measure of the contributing area. }\end{array}$ \\
\hline $\operatorname{Aspect}(\mathrm{A})^{\circ}$ & $\begin{array}{l}\text { Direction of the maximum rate of change in the elevation from each cell DEM so } \\
\text { aspect is the direction of gradient. It is shows the direction of substance flows. } \\
A=\arctan \left(\frac{q}{p}\right)^{a}\end{array}$ \\
\hline Elevation. $\mathrm{M}$ & Elevation above sea level. \\
\hline Tangential curvature (Tang) & Plan curvature multiplied by the slope. \\
\hline Dispersal area & Area downslope from a short length of contour \\
\hline
\end{tabular}

To reflect on the erosive power of the terrain, stream transport index (STI) was calculated using the Equation 2.

$$
S T I=(S C A / \mathbf{2 2 . 1 3})^{m}(\sin S / \mathbf{0 . 0 8 9 6})^{n}
$$

where, " $\mathrm{A}_{\mathrm{s}}$ " is the specific catchment area, " $\beta$ " is the slope degree, and " $\mathrm{m}$ " and " $\mathrm{n}$ " are constant parameters (Wilson and Gallant 2000).

The distribution of topographic attributes within the studied area derived from the DEM is shown in Figure 3.

\subsection{Statistical analysis}

Descriptive statistics of the experimental data including mean, minimum, maximum, range, standard deviation (SD), variance, and skewness were determined using the software statistical SPSS (IBM Com., Chicago, USA). Correlation coefficients to define relationships between soil depth and terrain attributes, and analysis of variance (ANOVA) by Duncan test were done using the SPSS software.

In this study, the statistical software SPSS (IBM Com., Chicago, USA) was used for developing multiple linear regression models. Terrain attributes were selected as the independent variables and soil depth was employed as dependent variable in the model. One hundred sampling sites were divided into data sets, $70 \%$ and $30 \%$ for modeling and validation processes, respectively. The data sets for modeling and validation processes were selected randomly at different points on the landscape in the field to avoid biases in estimation.

Thirty sampling sites were used to validate the developed soil-landscape model. In testing soillandscape model, we calculated two indices from the observed and predicted values suggested by Odeh et al. (1994), and included mean error (ME) 

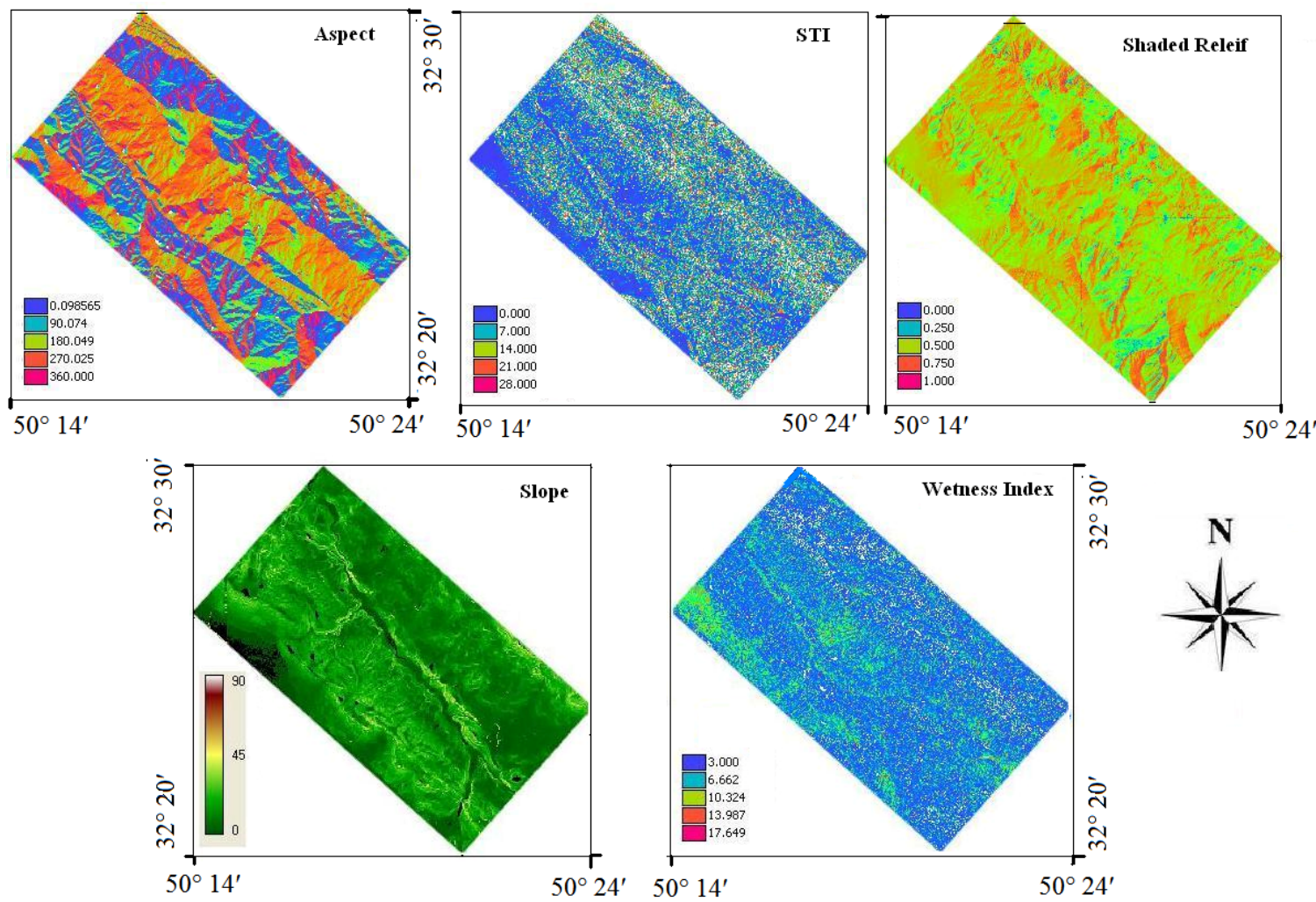

Figure 3 Topographic attributes (aspect, sediment transport index, shaded relief, slope, and wetness index) derived form the digital elevation model of the studied area.

and root mean square error (RMSE) as follows:

$$
\begin{aligned}
& M E=\sum\left[z^{*}(s j)-z(s j)\right] / n \\
& R M S E=\left\{\sum\left[\mathrm{z}^{*}(s j)-z(s j)\right]^{2} / n\right\}^{1 / 2}
\end{aligned}
$$

where, $\mathrm{Z}(s j)$ and $\mathrm{Z}^{*}(s j)$ are the observed and predicted values of soil depth for validation data set ( $\mathrm{n}=$ number of data set). $M E$ measures the bias of the predicted value and should be close to zero for unbiased methods. RMSE is a measure of the precision of the predicted value and should be as small as possible for unbiased precise prediction.

\section{Results and Discussion}

\subsection{Descriptive statistical analysis}

Descriptive statistics for soil properties, soil depth and terrain attributes are given in Table 3. The soil depth in the studied profiles varied from $30 \mathrm{~cm}$ to $150 \mathrm{~cm}$ with an average of $108.6 \mathrm{~cm}$. Coefficient of variation (CV) was calculated to estimate and explain the variability in soil depth. Relatively high variability $(\mathrm{CV}=76 \%)$ was obtained for soil depth in the study area. It seems that the high variability for soil depth in the studied area depends on topography of the field, and the landscape position, causing differential accumulation of water at different positions on the landscape; and moreover the soil erosion and deposition processes, resulting in high variability in the soil depth. Kuriakose et al. (2009) reported that the CV values for soil depth varied from 45.93 to $80.82 \%$ in a landscape in Western Ghats of Kerala, India. Moreover, Vanwalleghem et al. (2010) in a study on spatial prediction of soil horizon depth using topographic attributes, reported CV values of 50.00, 28.26, 21.05\% for E, $\mathrm{Bt}$ and $\mathrm{BC}$ horizons, respectively.

\subsection{Correlation analysis}

The linear correlation analysis of the 12 topographic attributes and one soil property (soil depth), showed that there was a significant 
Table 3 Summary statistics for soil depth and terrain attributes at the 100 selected pointed at the site studied

\begin{tabular}{|l|l|l|l|l|l|l|l|}
\hline Variable & Unit & Minimum & Maximum & Mean & Skewness & Kurtosis & Range \\
\hline Soil depth & $\mathrm{cm}$ & 30 & 150 & 108.63 & 0.43 & 1.78 & 120 \\
\hline Elevation & $\mathrm{m}$ & 2337.30 & 2773.40 & 2510.44 & 0.61 & 1.22 & 436.10 \\
\hline Aspect & $\mathrm{o}$ & 1.00 & 359.89 & 210.97 & -0.43 & -0.72 & 358.89 \\
\hline CA & $\mathrm{m}^{2}$ & 100.06 & 69539.54 & 2531.44 & 0.89 & 0.98 & 69439.54 \\
\hline TangC & $1 / \mathrm{m}$ & -1.78 & 1.22 & 0.03 & -0.68 & 3.01 & 3.00 \\
\hline PLANC & $1 / \mathrm{m}$ & -0.04 & 0.05 & -0.58 & 0.44 & 2.09 & 0.09 \\
\hline PROFC & $1 / \mathrm{m}$ & -1.28 & 1.01 & 0.013 & -0.39 & 4.70 & 2.29 \\
\hline Shaded relief & - & 0.22 & 0.73 & 0.47 & 0.47 & -1.27 & 0.51 \\
\hline STI & - & 4.84 & 44.90 & 24.87 & 0.87 & 2.90 & 40.06 \\
\hline Slope & $\%$ & 0.00 & 21.17 & 10.58 & 0.62 & 0.85 & 21.17 \\
\hline WI & - & 3.39 & 12.00 & 7.69 & 0.83 & 1.20 & 8.61 \\
\hline DispA & $\mathrm{m}^{2}$ & 100.06 & 41423 & 1861 & 1.01 & 3.33 & 41322.9 \\
\hline
\end{tabular}

CA: Catchment area; TangC: Tangential curvature; PLANC: Plan curvature; PROFC: Profile curvature; STI: Sediment transport index; WI: Wetness index; DispA: Dispersal area.

Table 4 Pairwise correlation coefficients among soil depth and terrain attributes at the site studied $(n=100)$

\begin{tabular}{|c|c|c|c|c|c|c|c|c|c|c|c|c|c|}
\hline & SD & Elev & ASP & $\mathrm{CA}$ & TangC & PlanC & ProfC & Shad & STI & SPI & Slope & WI & DispA \\
\hline SD & 1 & & & & & & & & & & & & \\
\hline Elev & $-0.23^{*}$ & 1 & & & & & & & & & & & \\
\hline Asp & -0.09 & 0.04 & 1 & & & & & & & & & & \\
\hline $\mathrm{CA}$ & $0.65^{* *}$ & 0.03 & 0.04 & 1 & & & & & & & & & \\
\hline TangC & $0.23^{*}$ & 0.04 & 0.03 & 0.09 & 1 & & & & & & & & \\
\hline PlanC & $0.66^{* *}$ & -0.01 & -0.04 & 0.19 & $0.66^{* *}$ & 1 & & & & & & & \\
\hline ProfC & $0.20^{*}$ & 0.03 & 0.02 & 0.06 & $0.70^{* *}$ & $0.44^{* *}$ & 1 & & & & & & \\
\hline Shad & 0.12 & -0.01 & $0.60^{* *}$ & -0.06 & 0.04 & 0.06 & 0.11 & 1 & & & & & \\
\hline STI & $-0.73^{* *}$ & 0.08 & -0.11 & $0.61^{* *}$ & $0.44^{* *}$ & $0.29^{* *}$ & $0.21^{*}$ & -0.03 & 1 & & & & \\
\hline SPI & $-0.68^{* *}$ & 0.11 & -0.17 & $0.56^{* *}$ & $0.56^{* *}$ & $0.33^{* *}$ & $0.23^{*}$ & -0.05 & $0.76^{* *}$ & 1 & & & \\
\hline Slope & $-0.76^{* *}$ & -0.12 & -0.18 & -0.07 & 0.16 & $0.28^{* *}$ & 0.01 & -0.04 & $0.41^{* *}$ & $0.33^{* *}$ & 1 & & \\
\hline WI & $0.71^{* *}$ & 0.06 & 0.11 & $0.61^{* *}$ & $0.42^{* *}$ & $0.23^{* *}$ & $0.31^{* *}$ & 0.01 & $0.48^{* *}$ & $-0.41^{* *}$ & $-0.38^{* * *}$ & 1 & \\
\hline DispA & 0.14 & 0.04 & 0.13 & -0.07 & $-0.41^{* *}$ & $-0.37^{* *}$ & $-0.24^{* *}$ & 0.03 & -0.15 & -0.10 & -0.09 & $0.20^{*}$ & 1 \\
\hline
\end{tabular}

* Correlation is significant at the 0.05 level (2-tailed); ** Correlation is significant at the 0.01 level (2-tailed); SD = Soil depth.

correlation among 36 of the 77 attribute pairs $(\mathrm{P}<$ 0.01, and $\mathrm{P}<0.05$ ) (Table 4). Soil depth in the study area showed high positive significant correlations with catchment area $(\mathrm{r}=0.65, \mathrm{P}<$ 0.01), plan curvature $(\mathrm{r}=0.66, \mathrm{P}<0.01)$, and wetness index $(\mathrm{r}=0.71 \mathrm{P}<0.01)$, and showed high negative correlation with sediment transport index $(\mathrm{r}=-0.73, \mathrm{P}<0.01)$, sediment power index $(\mathrm{r}=-$ $0.68, \mathrm{P}<0.01)$ and slope $(\mathrm{r}=-0.76, \mathrm{P}<0.01)$. Low positive significant correlations of soil depth were identified with tangential curvature $(\mathrm{r}=0.23, \mathrm{P}<$ $0.05)$, and profile curvature $(\mathrm{r}=0.20, \mathrm{P}<0.01)$. Moreover, soil depth was negatively correlated with elevation $(\mathrm{r}=-0.23, \mathrm{P}<0.05)$. The rest of the topographic attributes including aspect, shaded relief, and dispersal area were not significantly correlated with soil depth in the area studied.
Many of these relationships are similar to those found in other landscapes. As slope gradient increases, soil and A-horizon depth tends to decrease (Moore et al. 1991; Gessler et al. 2000; Thompson et al. 2006). Florinsky et al. (2002) in a study on the prediction of solum depth using topographic attributes indicated that there were negative significant correlations of solum depth with elevation, slope gradient, aspect, and curvature. They also found positive significant correlations between solum thickness and catchment area and sediment power index. Thompson et al. (2006) in the Pennyroyal region of Kentucky reported that A- horizon depth showed positive correlation with elevation and negative relationship with slope gradient. Tsai et al. (2001) in a forest landscape in Taiwan reported 
that solum thickness had non-significant negative $(\mathrm{r}=-0.011)$ and non-significant positive $(\mathrm{r}=0.095)$ correlation coefficients with elevation and aspect, respectively, whereas solum thickness had negative significant correlation $\left(r=-0.24^{* * *}\right)$ with slope gradient.

We found relatively high correlation coefficients of soil depth with two groups of topographic attributes. The first group included that controls the soil erosional processes. Sediment transport index and sediment power index; and slope as the indices of soil erosional processes across the hilly mountainous regions have negative correlation with soil depth. It is presumably an indicator of greater erosion and topsoil loss from shoulder and backslope locations with higher SPI, STI and slope and less soil loss or even deposition at footslope and toeslope positions, which have lower indices. The second group of topographic attributes such as wetness index and catchment area are dominantly attributed to water accumulation and soil genesis processes within the hillslope. Wetness index reflects the spatial distribution of water flow, and thus the accumulation processes in a closed catchment. Topography has a vital role in solum thickness by natural pathways, especially by water accumulation in concaves and downslope positions of landscape (Florinsky et al. 2002).

\subsection{Effect of slope position on soil depth}

The results of analysis of variance (ANOVA) showed that there are significant differences $(\mathrm{P}<$ 0.05) for soil depth among the selected slope positions in the studied area. The results of mean comparisons among slope positions are presented in Figure 4. The highest values of soil depth were observed in the downslope positions including footslope and toeslope. A significant difference was observed between two mentioned positions with summit position; and it seems that this position has been partially influenced by soil loss processes.

The lowest spoil depth was observed in shoulder position with the highest rate of soil erosion. Afshar et al. (2010) who made a study in the semiarid region in western Iran showed that the highest rate of soil loss amounting to approximately $180 \mathrm{t} \cdot \mathrm{ha}^{-1} \cdot \mathrm{y}^{-1}$ was observed for steep slope such as observed at the shoulder position.
They also reported similar deposit rate in flat and low land such as observed at footslopes. Tsui et al. (2004) in a study along a gradient in Taiwan showed that slope can control the movement of water and material in a hillslope, and contributes to the spatial differences in soil properties. Khormali and Ajami (2011) in hilly region in loessial deposits in northern Iran indicated that cultivation in steep slopes following deforestation, the surface and in some cases the subsurface horizons such as Argillic horizon had been degraded during 50 years. They also showed that degradation of the soils was the major process on the summit, shoulder and back slope positions, and deposition was the dominant process in the footslope position.

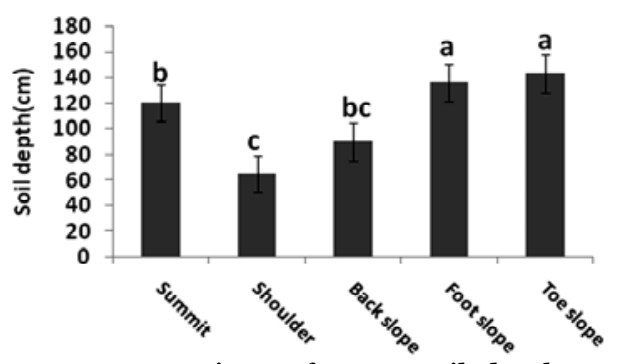

Figure 4 Comparison of mean soil depth among the slope positions in the studied area

\subsection{MLR analysis}

The results of ANOVA applied to MLR for soil depth using topographic attributes are presented in Table 5. As can be seen from the results, MLR provides significant explanation of soil depth using input variable. Empirical model (MLR) using selected terrain attributes explains $76 \%$ of the variation of soil depth in the studied area. The terrain attributes that best predicted soil depth variability in the selected site were mainly the attributes that had significant relationships with soil depth. The dominant attributes in the MLR model included slope, wetness index (WI), catchment area (CA) and sediment transport index (STI) as expressed in following regression equation (Equation 5):

$$
\begin{aligned}
& \text { Soil depth }(\mathrm{cm})=122.13-0.11 \text { Slope }+ \\
& \text { o.012WI }+0.012 C A-0.23 S T I \\
& p<0.001, R^{2}=0.76
\end{aligned}
$$

Slope gradient was identified as the most important predictor, and then WI, CA and STI 
were included in the predictor as important topographic attributes. Some significant attributes such as plan curvature, SPI were not included in the model developed, presumably induced by collinearity among these variables with variables included in the model. Vanwalleghem et al. (2010) in a study in forest in Belgium, for predicting the lower soil horizons depth, found significant relationships of soil depth with slope gradient, plan curvature and wetness index among the topographic predictors.

Table 5 Results of analysis of variance (ANOVA) for predicting soil depth using topographic attributes

\begin{tabular}{|l|l|l|l|l|l|}
\hline Model & $\begin{array}{c}\text { Sum of } \\
\text { square }\end{array}$ & df & $\begin{array}{c}\text { Mean of } \\
\text { square }\end{array}$ & F & P value \\
\hline Regression & 556.144 & 12 & 46.345 & 2.193 & 0.001 \\
\hline Residual & $1,711.752$ & 81 & 21.133 & & \\
\hline Total & $2,267.897$ & 93 & & & \\
\hline
\end{tabular}

Thompson et al. (2006) indicated that MLR models could explain $44 \%$ and $28 \%$ of the variability of A-horizon depth in east and central fields in the Pennyroyal region of Kentucky mainly with elevation, slope gradient, TCI and upslope contributing area. Penížek and Borůvka (2006) in southern Bohemia located in the Czech Republic, used regression kriging as compared with other interpolation approaches, for predicting spatial variability in soil depth and reported that aspect, altitude and slope were included in the MLR model developed. Ziadat (2010) using topographic attributes showed that MLR models predicted soil depth with a difference of $50 \mathrm{~cm}$ for $77 \%$ of the field observations within small watershed subdivision. A study in hillslopes of California by Gessler et al. (2000) indicated that models which utilize only CTI could explain $84 \%$ of variations in soil depth. Recently, Kuriaskose et al. (2009) using multiple regression model for prediction of soil depth in India, indicated that integration of topographic attributes and some auxiliary environmental variables such as rock out crops and land sue type improved the accuracy of the prediction at the watershed scale.

\subsection{Soil depth validation by MLR}

The results of the validation using 30 sampling sites are presented in Figure 5. A good agreement $(\mathrm{r}=0.88)$ existed between predicted and observed soil depth for the validation data set in various landscape positions. The ME and RMSE values provide additional indication of how well the models predict soil depth variability in the studied hillslopes. As expected, ME (0.004) and RMSE (1.23) values tended to be the lowest, and confirm the acceptable accuracy of the predictors in the study area.

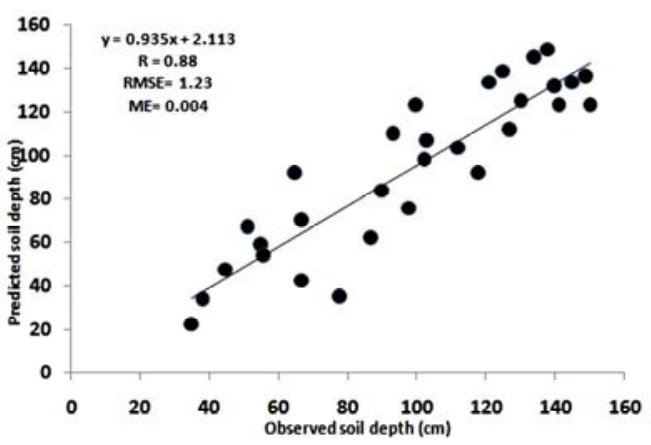

Figure 5 Scatterplot showing the relationship between predicted and observed soil depth by validation data set $(\mathrm{n}=30)$ in the studied area. ME: Mean error, RMSE: Root mean square error.

\section{Conclusions}

A soil-landscape modeling approach provides a framework for the assessment of soil variability among similar soil forming factors. We attempted to develop a simple and interpretive predictive model for soil depth in the hilly region of western Iran using DEM-derived attributes that are readily available, and provide cost effective information for use. The MLR modeling of measured soil depth and topographic attributes showed that this model could explain about $76 \%$ of the total variability in soil depth within the hilly region studied.

Slope, wetness index, catchment area, and sediment transport index were included as the most important variables for explaining the variability in soil depth. Overall, such topographic attributes directly or indirectly affected by pedogenic and erosional processes seem to control the soil depth in the hilly regions. The model developed in this study should be used and validated in other hillslopes with similar environmental conditions as in western Iran, to evaluate its overall accuracy for model transportability. Furthermore, there is need to test 
the DEM of different horizontal resolutions to distinguish the optimum DEM resolution to

\section{References}

Afshar FA, Ayoubi S, Jalalian A (2010) Soil redistribution rate and its relationship with soil organic carbon and total nitrogen using ${ }^{137} \mathrm{Cs}$ technique in a cultivated complex hillslope in western Iran. Journal of Environmental Radioactivity 101: 606-614.

Basso B (2005) Digital terrain analysis: Data source, resolution and application for modeling physical processes in agroecosystems. Rivista Italiana di Agrometeorologia 2: 5-14.

Boer M, Del Barrio G, Puigdefabregas J (1996) Mapping of soil depth in dry Mediterranean area using terrain attributes derived from a digital elevation model. Geoderma 72: 99-118.

Campling P, Gobin A, Feyen J (2002) Logistic modeling to spatially predict the probability of soil drainage classes. Soil Science Society of America Journal 66: 1390-1401.

Debella-Gilo M, Etzelmuller B (2009) Spatial prediction of soil classes using digital terrain analysis and multinomial logistic regression modeling integrated in GIS: Examples from Vestfold County, Norway. Catena 77: 8-18.

Florinsky IV, Eilers RG, Manning GR, et al. (2002) Prediction of soil properties by digital terrain modeling. Environmental Modeling and Software 17: 295-311.

Gessler PE, Chadwick OA, Charman F, et al. (2000) Modeling soil-landscape and ecosystem properties using terrain attributes. Soil Science Society of America Journal 64: 20462056.

Hengl T, Toomanian N, Reuter H, et al. (2007) Methods to interpolate soil categorical variables from profile observations: Lessons from Iran. Geoderma 140: 417-427.

Iran Metrological Organization (2012). Meteorological data of Charmahal and Bakhtiari Province. Available at http://irimo.ir/tmax.pdf. (Accessed: 12 January 2012).

Kalivas DP, Triantakonstantis DP, Kollias VJ (2002) Spatial prediction of two soil properties using topographic information. The Global Nest: the International Journal 4(1): 41-49.

Khormali F, Ajami M (2011) Pedogenetic investigation of soil degradation on a deforested loess hillslope of Golestan Province, Northern Iran. Geoderma 274- 283.

Kuriakose SL, Devkota S, Rossiter DG (2009) Prediction of soil depth using environmental variables in an anthropogenic landscape, a case study in the Western Ghats of Kerala, India. Catena 79: 27-38.

McBratney AB, Mendonca Santos ML, Minasny B (2003) On digital soil mapping. Geoderma 117: 3-52.

Meyer MD, North MP, Gray AN, et al. (2007) Influence of soil thickness on stand characteristics in a Sierra Nevada mixedconifer forest. Plant and Soil 294: 113-123.

Minasny B, McBratney AB (1999) A rudimentary mechanistic model for soil production and landscape development. Geoderma 90: 3-21.

Moore ID, Hutchinson MF (1991) Spatial extension of achieve more accurate soil landscape modules.

hydrologic process modeling. Proc. Int. Hydrology and Water Resources Symposium. Institution of Engineers-Australia 91/22. pp. 803-808.

Mueller TG, Pierce FJ (2003) Soil carbon maps: Enhancing spatial estimates with simple terrain attributes at multiple scales. Soil Science Society of America Journal 67: 258-267.

Norouzi M, Ayoubi S, Jalalian A, et al. (2009) Predicting rainfed wheat quality by artificial neural network using terrain and soil characteristics. Acta Agriculturae Scandinavia, Section BSoil and Plant Science 60: 341-352.

Odeh IOA, Chittleborough DJ, McBratney AB (1991) Elucidation of soil-landform interrelationships by canonical ordination analysis. Geoderma 49: 1-32.

Odeh IOA, McBratney AB, Chittleborough DJ (1994) Spatial prediction of soil properties from landform attributes derived from a digital elevation model. Geoderma 63: 197-214.

Penizek V, Boruka L (2006) Soil depth prediction supported by primary terrain attributes: a comparison of methods. Plant Soil Environment 52: 424-430.

Saulnier GM, Beven K, Obled C (1997) Including spatially variable effective soil depths in TOPMODEL. Journal of Hydrology 202: 158-172.

Soil Survey Staff (2006) Keys to Soil Taxonomy, 10th ed USDANatural Resources Conservation Service, Washington, DC, USA.

Thompson JA, Bell JC, Butler CA (1997) Quantitative soil- landscape modeling for estimating the areal extent of hydromorphic soils. Soil Science Society of America journal 61: 971-980.

Thompson JA, Pena-Yewtukhiw EM, Grove JH (2006) Soillandscape modeling across a physiographic region: Topographic patterns and model transportability. Geoderma 133: 57-70.

Tsai CC, Chen ZS, Duh CT, et al. (2001) Prediction of soil depth using a soil landscape regression model: a case study on forest soils in southern Taiwan. National Science Council of the Republic of China, Part B: Life Sciences 25: 34-39.

Vanwalleghem T, Poesen J, McBratney A, et al. (2010) Spatial variability of soil horizon depth in natural loess-derived soils. Geoderma 157: 37-45.

Wilson JP, Gallant JC (200o) Secondary Topographic Attributes. In: Wilson JP and Gallant JC (eds), Terrain Analysis: Principles and Applications. New York, John Wiley and Sons: 87-131.

Zhu AX, Hudson B, Burt J, et al. (2001) Soil mapping using GIS, expert knowledge, and fuzzy logic. Soil Science Society of America Journal 65: 1463-1472.

Ziadat FM (2005) Analyzing digital terrain attributes to predict soil attributes for a relatively large area. Soil Science Society of America Journal 69: 1590-1598. 